\title{
Analysis of stem and root extract of kepok banana (musa paradisiaca Linn.) in inhibit staphylococcus aureus growth
}

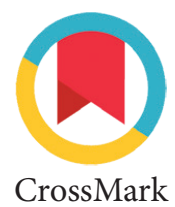

\author{
Harlina, Octhavya PD. Pradana*
}

\section{Abstract}

Objective: To Determine stem and root activity of banana plants kepok in inhibiting the growth of staphylococcus aureus.

Material and Methods: The study was an experimental laboratory to design a post-test only controlgroup. Extract the stem and roots of kepok banana plants. Obtained by maceration using methanol. The extract Obtained each diluted into a concentration of $6.25 \%$, $12.5 \%$ and $25 \%$. DMSO $10 \%$ and distilled water as the diluent. Inhibition of the extract was tested by paper disc diffusion method on Mueller-Hinton media agar. Major inhibitory stem, root extracts of kepok banana seen by the diameter of inhibition formed around the paper discs.

Results: The average diameter formed on the stem extract concentration of $6: 25 \%, 12.5 \%$ and $25 \%$ respectively was $11,17 \mathrm{~mm}, 9.86 \mathrm{~mm}$ and $9.72 \mathrm{~mm}$. Root extract with a concentration of $6: 25 \%, 12.5 \%$ and $25 \%$ respectively are 8:16 am, 7:36 and 7:43 $\mathrm{mm} \mathrm{mm}$. Retrieved $p=0.000$ $(P<0.05)$ for each of the stems and roots.

Conclusion: Stem and roots of kepok banana plants had activity in inhibiting the growth of bacteria staphylococcus aureus.

Keywords: Inhibiton, Kepok Banana plants, S. aureus,

Cite This Article: Harlina, Pradana OPD. 2019. Analysis of stem and root extract of kepok banana (musa paradisiaca Linn.) in inhibit staphylococcus aureus growth. Journal of Dentomaxillofacial Science 4(1): 45-48. D01: 10.15562/jdmfs.v4i1.877

Department of Oral Medicine, Faculty of Dentistry, Hasanuddin University, Makassar, Indonesia
*Correspondence to: 0cthavya PD. Pradana, Department of Oral Medicine, Faculty of Dentistry, Hasanuddin University, Makassar, Indonesia putri.devin@gmail.com

Received: 28 January 2019 Revised: 25 February 2019 Accepted: 15 April 2019 Available Online 1 April 2019

\section{Introduction}

The typed of plants as natural products for human health. Particularly in the last decade, there is much more intensive research for therapies utilizing natural materials. Approximately $80 \%$ of individuals in developing countries use traditional medicine that is largely mixtures derived from plants. So far there are various kinds of plants used as medicine, one of which is banana. ${ }^{1}$

Banana plants of the genus Musa (family: musaceae) is a native plant of Asia, Indo-Malaysia and Australia. This species is now widely spread in the area of tropical and sub-tropical. Banana plant is often used as groceries and traditional medicines both parts of the fruit, leaf, stem, stems and roots. Banana plants have been studied as an anti-ulcer, anti-bacterial and plays a role in wound healing. Bananas are traditionally used to treat diarrhea, dysentery disorders, lesions/wounds, diabetes mellitus, uremia, hypertension and heart disease. ${ }^{2}$

Plants on earth in general have an active compound in the form of metabolites secondary such as flavonoids, tannins, alkaloids, steroids and saponins. Secondary metabolites are chemical compounds commonly used to protect plants from pests diseases. Banana fruit pulp contains carbohydrates, norepinephrine, serotonin, dopamine, tryptophan, indole compounds, alkaloids, tannins, ascorbic acid, some flavonoids and related compounds (leucocyanidin, rhamnosyl O-glucoside).
Sterols are composed of $\beta$-sitosterol, campesterol, stigmasterol contained in fruits and leather. Sitoindoside-I, sitoindoside-II, sitoindoside sitoindoside III and IV which have a role unulserogenic also contained in bananas. Antihypertensive potential is found in the rind. The roots of banana plants contain substances such as alkaloids, steroids flavonoids, saponins and tannins. ${ }^{3}$ Based on tests on water banana stem phytochemical kepok by Maya et al. ${ }^{4}$ showed that the banana stems in water kepok found tannins, alkanoid, and saponins, but not with flavonoids and steroids. The content inside is what makes the banana plant banana plant has a role as an anti-ulcer, anti-bacterial, and plays a role in wound healing., ${ }^{2,4}$

Indonesia is one country that has various kind of banana. Every region in Indonesia has a typical banana plant. Especially in South Sulawesi, famous for kepok banana which is often processed into typical snacks of Makassar namely "Pisang Epe". In addition, kepok banana (also called saba) fruit can be processed into other foods such as fried bananas, chips, etc or other plant parts can also be used as medicines given that the previously mentioned benefits of bananas as a drug. In the study by Maya et al. ${ }^{4}$ suggested that the banana plant has an effect on some bacteria, one of which is staphylococcusaureus. ${ }^{4}$ Some of oral infections caused by staphylococcusaureus, Angular cheilitis, mumps and staphylococcal mucositis. ${ }^{5}$ These microbes resistant to penicillin oxacillin and other 
beta-lactam antibiotics. ${ }^{6}$ The content of tannins, flavonoids, alkaloids and saponins in banana function as an antiseptic, inhibit the growth of S. aureus, thus accelerating the growth of new cells and stimulates the growth of fibroblasts.?

The chemicals contained in kepok banana certainly have effectiveness against $\mathrm{S}$. aureus different because it is influenced by the concentration of these substances. Compares the condensed extract from some parts of banana plants kepok yellow, viscous extract from banana plant stem yellow kepok greatest effect against $S$. aureus followed by a condensed extract of the roots of banana yellow kepok. This attracted the attention of the author to examine the activity of the substances contained in the extract of stems and roots of banana plants kepok against staphylococcus aureus.

\section{Material and Methods}

The study was an experimental laboratory with post test only control group design. Stem and roots of kepok banana were extracted in the Laboratory of Phytochemistry, Faculty of Pharmacy Hasanuddin University. Inhibition observation of kepok banana stem and root extract toward S.aureus was conducted at Laboratory of Microbiology, Faculty of Pharmacy, Hasanuddin University. The research material used in this study is the stem and roots of kepok banana, aquadest, mueller hilnton agar (MHA), sodium agar (NA), staphylococcus aureus, methanol 100\% and 10\% DMSO. The tools used in this study was bottle of maceration (pyrex), rotary evaporator (heidolph), the petri dish (pyrex), test tubes (pyrex), ose round (pyrex), tube flask (pyrex), autoclave (25x-2serial no. 010763), oven (ecocell), incubator (memmert WTBD-100), a micropipette, laminary air flow (envirco), paper discs (oxoid antimicrobial susceptibility testdisc), caliper (krisbow) and digital scales (AcisAD-60H).

Research procedure begins with taking kepok banana stems and roots. Kepok banana plant (roots and stems) is washed under running water, then drain. Then the stem and roots of kepok banana cuts into small pieces and taken each as 500 grams, then dried in the sun indirectly (coated with a black cloth) for \pm 2 days followed by oven for 2 days at a temperature of $400 \mathrm{C}$ until the sample stems and roots of kepok banana completely dry. After drying, followed with the extraction process. Extraction of the stem and roots of banana plants kepok by maceration. Each sample stems and roots of banana plants kepok soaked with methanol in the bottle sealed maceration for 3 days ( 3 × 24 hours) days, filtered and the filtrate thus obtained were accommodated in the shelter container (bottle maceration). The entire filtrate that obtained concentrated by rotary evaporator at a temperature $50^{\circ} \mathrm{C}$ to obtain a thick extract.

In this study, the dilution into concentration: $6.25 \%, 12.5 \% ; 25 \%$. At the dilution supplied DMSO $10 \%$ as a diluent. Each concentration is diluted into a volume of $1 \mathrm{ml}$.

To obtain the extract with a concentration of $6.25 \%$; taken as much as 0.06 grams of viscous extract, then added DMSO $0.1 \mathrm{ml}$ and then added again withof sterile distilled 0.9 mlwater, to obtain the extract with a concentration of $12.5 \%$; taken as much as 0.12 grams of viscous extract, then added DMSO $0.1 \mathrm{ml}$ and then added again with $0.9 \mathrm{ml}$ of sterile distilled water, to obtain the extract with a concentration of $25 \%$; condensed extract taken as much as 0.25 grams, then added DMSO $0.1 \mathrm{ml}$ and then added again with aquadest $0.9 \mathrm{ml}$.

Mueller Hilnton order made as much as $150 \mathrm{ml}$, placed in a tube flask. Sodium to be made as much as $10 \mathrm{ml}$, laid role in tubes. Test then both sterilized using an autoclave.

Colonies of bacteria (stock culture) were taken using roun Ose and suspended into a tube containing media NA (sterilized) with inscribed.

Inhibition test was done by using paper disc diffusion method. The results of the test power Antibacterial based on measurements Diameter Inhibitory Power (DDH) growth of bacteria that formed around the paper disc. Extract the stem and roots plants of kepok banana that different concentrations $(6.25 \%$, $12.5 \%$, and $25 \%$ ) and $10 \%$ DMSO solution as a control, respectively dropped on the paper as much as $20 \mathrm{~mL}$ sterile disc, and then wait until becomes saturated.

Then as much as $0.01 \mathrm{ml}$ of the test bacteria suspension was inoculated evenly on a medium Mueller Hinton Agar (MHA). Wait a few minutes until the paper disc dry, then place the abovementioned paper disc media that have solid MHA. Furthermore incubated at $37^{\circ} \mathrm{C}$ for 24 hours. After 24 hours, the diameter of the area that formed around the paper discs were observed and measured using a caliper.

\section{Results}

As previously mentioned, extract thick stems and roots of banana plants kepok each made into three different concentration; $6.25 \%, 12.5 \%$ and $25 \%$. Then testing the inhibition of diffusion method. Incubated for 24 hours in order to obtain the results as shown below: $\mathrm{B} 1=6.25 \%$ extract stem, Stem extract B2 $=12.5 \%, \mathrm{~B} 3=$ stem extract $25 \%$, $\mathrm{A} 1=\operatorname{root}$ extract $6.25 \%, \mathrm{~A} 2=$ root extract $12.5 \%$, 
Table 1 Results of inhibition zone diameter measurement

\begin{tabular}{lccccc}
\hline $\begin{array}{l}\text { Sample } \\
\text { extract }\end{array}$ & $\begin{array}{c}\text { Concentration } \\
(\mathbf{\%})\end{array}$ & \multicolumn{2}{l}{ Inhibition zone diameter $(\mathbf{m m})$} & Average diameter zone $(\mathbf{m m})$ \\
\cline { 3 - 6 } & & \multicolumn{2}{l}{ Measurement I Measurement II Measurement I Measurement II } \\
\hline Stem & 6.2 & 10.77 & 11.43 & 11.3 & 11.17 \\
& 12.5 & 9.56 & 9.64 & 10.38 & 9.86 \\
\multirow{2}{*}{ Root } & 25 & 10.23 & 9.73 & 9.2 & 9.72 \\
& 6.25 & 8.12 & 8.45 & 7.92 & 8.16 \\
& 12.5 & 7.6 & 7.28 & 7.2 & 7.36 \\
\hline
\end{tabular}
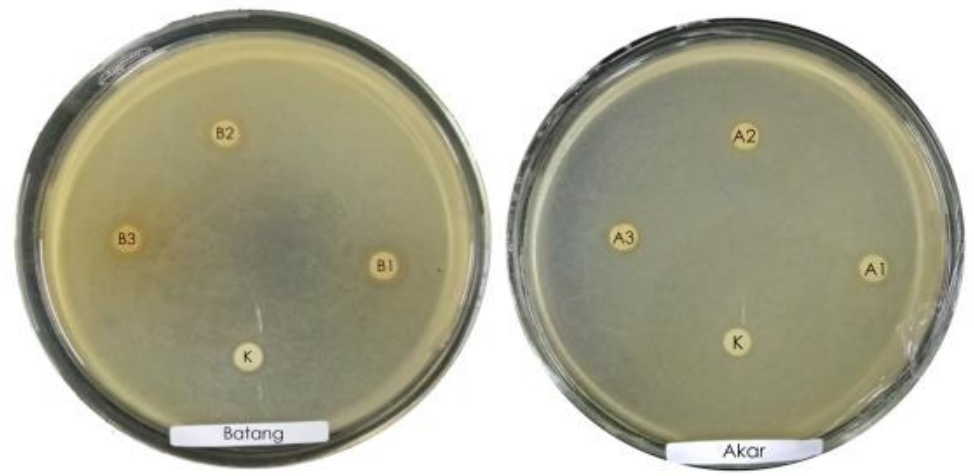

Figure 1 Colonies S. aureus that have been treated

Table 2 Results of the average diameter and standard deviation

\begin{tabular}{lccccc}
\hline Group & $\begin{array}{c}\text { Concentration } \\
(\mathbf{\%})\end{array}$ & $\mathbf{N}$ & $\begin{array}{c}\text { Average } \\
\text { inhibition zone } \\
\text { diameter }(\mathbf{m m})\end{array}$ & $\begin{array}{c}\text { Standard } \\
\text { deviation }\end{array}$ & p-value \\
\hline \multirow{3}{*}{ Stem } & 6.25 & 3 & 11.17 & 0.35 & $0.357^{*}$ \\
& 12.5 & 3 & 9.86 & 0.45 & $0.169^{*}$ \\
& 25 & 3 & 9.72 & 0.51 & $0.968^{*}$ \\
Root & 6.25 & 3 & 8.16 & 0.27 & $0.731^{*}$ \\
& 12.5 & 3 & 7.36 & 0.21 & $0.363^{*}$ \\
& 25 & 3 & 7.43 & 0.31 & $0.314^{*}$ \\
\hline
\end{tabular}

${ }^{*}$ Data Normality Test: Shapiro-Wilktest;p> 0.05; normal data distribution; IK95\%

Stem extract B2 $=12.5 \%, \mathrm{~B} 3=$ stem extract $25 \%, \mathrm{~A} 1$ $=$ root extract $6.25 \%, \mathrm{~A} 2=$ root extract $12.5 \%, \mathrm{~A} 3=$ root extract $25 \%, \mathrm{~K}=$ control $(\mathrm{DMSO} 10 \%)$.

In figure 1 showed inhibitory zone with no firm boundaries around the paper disc. The results measurement inhibitory of the concentrations against S. aureus bacteria are presented in table 1 .

All the results of inhibition zone diameter measurements in the laboratory were subsequently collected and recorded, as well as data processing and analysis performed using SPSS version 23 (SPSS Inc., Chicago, IL, USA). The results of the study are displayed in table 2.

All the results of inhibition zone diameter measurements in the laboratory subsequently collected and recorded, as well as data processing and analysis performed using SPSS version 23
(SPSS Inc., Chicago, IL, USA). The results of the study are displayed in table 2.

From table 2 it can be seen that the extract had an average diameter of the largest rod that is extract $6.25 \%(11.17 \mathrm{~mm})$, then followed was extract $12.5 \%(9.86 \mathrm{~mm})$, extract the stem $25 \%$ $(9.72 \mathrm{~mm})$, root extract $6.25 \%(8.16 \mathrm{~mm})$, root extract $25 \%(7.43 \mathrm{~mm})$ and the smallest is $12.5 \%$ root extract that is $7.36 \mathrm{~mm}$.

To investigate the activity of stem and root extracts kepok banana plants (musa paradisiaca Linn.) In inhibiting the growth of bacteria S. aureus, then used ANOVA. But first, you need to know the distribution of normal data or not, using the Shapiro-Wilk test. In table 2. The obtained value of $p>0.05$, which indicates that the data were normally distributed, then followed by oneway ANOVA test. From one way ANOVA test results obtained value of $p<0.05$ is 0.000 , which means there is a significant difference between the inhibitory concentration extract kepok banana stems and roots. Thus the Ho accepted. So these results are further processed by using Post Hoc Test to see which groups are different.

Based on the Post Hoc Test found that there were significant differences between the inhibition of the stem extract concentration of $6.25 \%$ by stem extract concentration of $12.5 \%$. A significant difference was also found in the stem extract inhibitory concentration of $6.25 \%$ by stem extract concentration of $25 \%$. But there was no significant difference between the inhibition of the stem extract concentration of $12.5 \%$ by stem extract concentration of $25 \%$. Also were no significant difference between the inhibition of root extract concentration of $6.25 \%, 12.5 \%$ and $25 \%$. Retrieved $\mathrm{p}<0.05$, which means there were significant differences between the groups with the root extract stem extract group kepok banana.

\section{Discussion}

Based on the results of the study, extracts of stems and roots of banana plants kepok have inhibitory effects and different to bacteria S.aureus. The results of analysis the data pointed right that there are significant differences between the activity of extracts of stems and roots of banana plants kepok against bacterial growth of S.aureus. It is known that extracts the banana plant stem kepok have greater influence in inhibiting growth bacterial when compared with root extract, amounting to $11.17 \mathrm{~mm}$. That the lumpy extract tuber (stem) kepok yellow banana plant has the impact most on the growth of test bacteria (S.aureus), which amounted to $20.39 \mathrm{~mm}$. The antibacterial activity of methanol extract stem 
mauli banana (musasp) against streptococcus mutans, it is evident that the methanol extract of banana stem mauli has a effect bacteriostatic against streptococcus mutans at a concentration of $6.25 \%, 12.5 \%$ and $25 \%{ }^{8}$

There are differences in inhibition zone diameter such as extracts of different concentrations; different extract dilution; dilute extract in $5 \mathrm{ml}$ whereas in this study were $1 \mathrm{ml}$, the difference in the other is the sample is the ethanol extract thick stems and roots, strains of different bacteria will influence different despite coming from the same species and different varieties of plants used; influenced by the state of site, the nutrients obtained from around the area grows, etc.

If the inhibition zone formed on the diffusion test measuring less than $5 \mathrm{~mm}$, categorized weak inhibition. If the inhibition zone measuring $5-10 \mathrm{~mm}$ categorized as moderate, strong and categorized $10-19 \mathrm{~mm}$ over $20 \mathrm{~mm}$ categorized. ${ }^{9}$

From statements, it can be concluded that the inhibition of the stem extract concentration of $6.25 \%$ categorized as strong, where as inhibition of stem concentration of $12.5 \%$, a concentration of $25 \%$ stems, roots concentration of $6.25 \%, 12.5 \%$, and $25 \%$ is average.

Extracts of stem and root have inhibitory effect of moderate to severe, but still found around discs bacterial growth that has been poured stem and root extracts. Visible presence of bacterial growth in the less fertile around the paper disc than with the area outside the influence of the extract, inhibitory zone is not really clear. This situation is known as irradical zone. Irradical zone is an area around paper disc where growth bacterium only inhibited by antibacterial, do not be turned off. Which means that extracts stem and root at these concentrations growth merely inhibit the bacteria but do not kill the bacterial cell..$^{10}$ Active substances contained in a banana tree, such as flavonoids, saponins and tannins that work hand in hand so as to have an antibacterial effect. ${ }^{11}$

\section{Conclusion}

Based on the results of research conducted can be concluded that; extract stems kepok banana and roots of the banana plant extracts kepok had activity in inhibiting the growth of bacteria staphylococcusaureus, extract the rod has a effectiveness greater than the extract of the roots, in this case, kepok banana stem extract concentration of $6.25 \%$, $12.5 \%, 25 \%$,root extract banana concentration of $6.25 \%, 12.5 \%, 25 \%$ effect in inhibiting the growth of staphylococcusaureus significantly, recommended further studies using different medium and more varied extract concentration, should further studies using samples of banana plants more grow diverse and different locations.

\section{Acknowledgment}

The authors would like acknowledge thank you for the supporting Faculty of Dentistry Hasanuddin University of this research.

\section{Conflict of Interest}

The authors report no conflict of interest.

\section{References}

1. Karadi RV, Shah A, Parekh P, et al. Antimicrobial activities of musa paradisiaca dan Cocos nucifera. J Pharmaceutic \& Biomedic Sci 2011: 264-267.

2. Zafar MI, Saleha A, Hoque M, et al. Antimicrobial and cytotoxic properties of different extracts of Musa sapientum L. subsp. Sylvestris. J Pharmac 2011: 62-65.

3. Mohapatra D. Banan and its by-product utilisaition: an overview. J Sci \& Industrial Res 2010: 323-329.

4. Maya SW, Citraningtyas G, Lolo AW. Phytocemical screening and antiphyretic effect of stem juice from kepok banana (musa paradisiaca L) on white male rats stain wistar (rattus norvegicus) induced with DTP-Hb. JIF 2015.

5. Smith AJ, Robertson D, Tang MK, et al. Staphylococcus aureus in the oral cavity: a three year retrospective analysis of clinical laboratory data. British Dent J 2003: 701-702.

6. Noor MA, Apriasari ML. Efektifitas antibakteri ekstrak metanol batang pisang mauli (musa acuminata) dan povidone iodine $10 \%$ terhadap streptococcus mutans. J PDGI 2014: 78-83.

7. Mardiastuti WH, Karuniawati A, Kiranasari A, et al. Emerging resisteance pathogen: situasi terkini Asia, Eropa, Amerika Serikat, Timur Tengah dan Indonesia. MKI 2007: 75

8. Apriasari ML, Fadhilah A, Carabelly AN. Aktivitas antibakteri ekstrak metanol batang pisang mauli (musa sp.) terhadap streptococcus mutans. J Dentomaxillofac Sci 2013;12: 148-150.

9. Ningsih AP, Nurmiati, Agustien A. Uji aktivitas antibakteri ekstrak kental tanaman pisang kepok kuning (musa paradisiaca Linn.) terhadap staphylococcus aureus dan escherichia coli. J Bio UA 2013: 207-213.

10. Mierziak J, Kostyn K, Kulma A. Flavonoids as important molecules of plant interaction with the environtment. Molecules 2014: 16240-16265.

11. Ashok PK, Upadhayaya K. Tannins are astrigent. J Pharmac \& Phytochem 2012: 45-49.

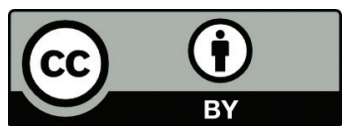

This work is licensed under a Creative Commons Attribution 